\title{
Possible role of Cold Agglutinins in Pathogenesis of Acquired Autoimmune Hemolytic Anemia
}

\author{
Authors \\ AK Kapoor ${ }^{1}$, Pratishtha Rastogi ${ }^{2}$, Akanksha Singh $^{3}$, Surbhi Rajauria ${ }^{4}$, Divya Saxena ${ }^{5}$ \\ Surabhi Maheshwari ${ }^{6}$ \\ 1,3,4,5 Pathologist, RML Mehrotra Pathology Pvt Ltd, Lucknow, UP, India \\ ${ }^{2}$ Senior technician, RML Mehrotra Pathology Pvt Ltd, Lucknow, UP, India \\ Corresponding Author \\ Ashok Kumar Kapoor
}

D87 Mahanagar Extension, Vigyan Puri, Lucknow, UP, India

Email: drashokkapoor2016@gmail.com

\begin{abstract}
Present study relates to the results of detection of high-titer cold anti I antibodies in sera of 3 patients with anemia. Age of the patients ranged from 15 to 67 (median 30) years. Characterization of immune complexes on sensitized erythrocytes revealed presence of $\operatorname{IgM}, \operatorname{IgGI}, \operatorname{IgG3}, \operatorname{IgA}, C 3 \mathrm{c}$ and $C 3 d$ in a patient, suggesting a diagnosis of cold agglutinin disease (CAD). Another case had IgG1, IgG3, IgA, C3c and $C 3 d$, suggesting a diagnosis of paroxysmal cold hemoglobinuria (PCH). Another patient had C3d alone on their erythrocytes, suggesting dissociation of immunoglobulins from red cell membranes. Findings of this study suggest possible role of cold agglutinins in pathogenesis of autoimmune hemolytic anemia.

Keywords: Heterophil anti I antibody, $\operatorname{IgM}, \operatorname{IgG}$.
\end{abstract}

\section{Introduction}

Cold agglutinins are known to develop following certain microbial infections, e.g. mycoplasma pneumonia, infectious mononucleosis and ancylostomiasis due to heterophil antibody formation. Microbial heterophil antibody is polyclonal $\operatorname{IgM}(\kappa$ and $\lambda$ ). Specificity of auto reactive cold agglutinins may be directed against I or $\mathrm{i}$ antigens. I antigens are expressed on adult human erythrocytes while i antigens are mainly expressed on cord-blood red cell membranes. CAD is a direct extravascular anti-human immunoglobulin positive hemolysis ${ }^{1}$. IgM may activate and fix complement components. Later, monocyte-macrophages may eliminate $\mathrm{C} 3 \mathrm{~b}$ coated erythrocytes, resulting in mild anemia. Rarely, the cold autoantibody in CAD may be related to Waldenstrom's macroglobulinemia and IgM $\kappa$ antibody may be produced. The prevalence of primary CAD was 16 cases per million inhabitants and the incidence rate was 1 per million per year ${ }^{2}$. Conversely, cold agglutinin positive tests are much more frequent in hospital patients as evidenced by anti $\mathrm{C}$ serum ${ }^{3}$. Present study relates to the results of estimation of cold agglutinins in 3 patients with anemia. In addition, we also 
characterized immune complexes on surface membranes of patients' erythrocytes. As it will appear, composition of immune complexes was different in 3 patients.

\section{Material and Methods}

Age of the patients ranged from 15 to 67 (median 30) years. Male female ratio was 1:2. Venous blood samples were collected in 2 tubes. First sample was collected in a warm $\left(37^{\circ} \mathrm{C}\right)$ plain tube and serum was separated. Second sample was collected in cold EDTA tube $\left(+4^{\circ} \mathrm{C}\right)$ and red cells were washed in plenty of cold $\left(+4^{\circ} \mathrm{C}\right)$ normal saline. Serum sample was doubly diluted in saline. Later, $1 \%$ human blood group O RBC $\left(\mathrm{I}^{+}\right)$ were added at $+4^{\circ} \mathrm{C}$ overnight and examined. Cold agglutinin titer was obtained ${ }^{3}$. Normal titer was taken as $<64$ at $+4{ }^{\circ} \mathrm{C}$ as described earlier ${ }^{4}$.Pathologic cold agglutinins have titres well over 512.

Patient's washed RBCs were also used for characterization of immune complexes on sensitized erythrocytes by direct antiglobulin test (DAT). A card of several microtubes having columns of solid phase matrix mixed with anti- human immunoglobulins was used. Later, patient's sensitized RBCs were added. Tubes were centrifuged in ID-centrifuge at $+4^{\circ} \mathrm{C}$ for agglutinination ${ }^{4}$.Unagglutinated cells pass to the tip of the tube but agglutinates do not pass through the gel. As the antiglobulin serum is present in the microtubes, washing was not required. Later DAT was done to investigate the class of immunoglobulins and complement components on erythrocytes. Kits were purchased from Bio-Rad.

\section{Results}

Cold agglutinin titers of 3 patients were 128, 256 and $>512$ (table 1). Results of DAT revealed presence of IgM, IgG1, IgG3, IgA, C3c and C3d on erythrocyte surface in a patient (no.2). The patient was diagnosed as a case of cold agglutinin disease (CAD). Another patient (no.1) had $\mathrm{IgG1}$, IgG3, IgA, C3c and C3d on red cell membranes, possibly due to paroxysmal cold hemoglobinuria (PCH). Another patient (no.3) had C3d and lowtiter anti-humanIg on patient's RBC (table 1). Later finding suggested deagglutination or dissociation of immunoglobulins from patient's erythrocytes.

Table 1 : Characterization of immune complexes of cold haemagglutinins by direct antiglobulin test (DAT)

\begin{tabular}{|c|c|c|c|c|c|c|c|c|c|c|c|c|c|}
\hline No. & $\begin{array}{l}\text { Patient } \\
\text { ID }\end{array}$ & $\begin{array}{l}\text { Age in } \\
\text { yrs/gender }\end{array}$ & $\begin{array}{l}\text { Anti I } \\
\text { titer }\end{array}$ & DAT & $\begin{array}{l}\text { Anti } \\
\text { HIg } \\
\text { DAT }\end{array}$ & $\begin{array}{l}\text { Anti } \\
\text { HIgM } \\
\text { DAT }\end{array}$ & $\begin{array}{l}\text { Anti } \\
\text { HIgG } \\
\text { DAT }\end{array}$ & $\begin{array}{l}\text { Anti } \\
\text { HIgA } \\
\text { DAT }\end{array}$ & $\begin{array}{l}\text { Anti } \\
\text { C3c } \\
\text { DAT }\end{array}$ & $\begin{array}{l}\text { Anti } \\
\text { C3d } \\
\text { DAT }\end{array}$ & $\begin{array}{c}\text { Anti } \\
\text { H IgG1 } \\
\text { DAT }\end{array}$ & $\begin{array}{c}\text { Anti } \\
\text { HIgG3 } \\
\text { DAT } \\
\end{array}$ & Interpretation \\
\hline 1 & 11801190163 & $67 \mathrm{M}$ & $>512$ & + & 30 & - & + & + & + & + & 100 & 100 & $\begin{array}{l}\text { Paroxysmal cold } \\
\text { hemoglobinuria } \\
\text { (PCH) }\end{array}$ \\
\hline 2 & 11712200070 & $15 \mathrm{~F}$ & 128 & + & 1000 & + & + & + & + & + & 100 & 100 & $\begin{array}{c}\text { Cold agglutinin } \\
\text { disease (CAD) }\end{array}$ \\
\hline 3 & $11801210121 *$ & $30 \mathrm{~F}$ & 256 & + & $<10$ & - & - & - & - & + & - & - & $\begin{array}{l}\text { Cold agglutinin } \\
\text { disease (CAD) }\end{array}$ \\
\hline
\end{tabular}

Abbreviations : PCH = paroxysmal cold hemoglobinuria, $\mathrm{CAD}=$ Cold agglutinin disease. $\mathrm{H} \mathrm{Ig}=$ human immunoglobulin, + positive $*$ Last patient had mild anemia ( $\mathrm{Hb} 12.5 \mathrm{gm} / \mathrm{dl}$ ) and mild neutrophilia (neutrophils $9216 \mathrm{cells} / \mathrm{mm}^{3}$ ) suggesting transient cold agglutinin hemolytic anemia.

\section{Discussion}

Most important feature of this study was the detection of high-titer anti I antibody $(>512)$ in serum of one of the patients. In addition, this patient (no.1) also had IgG1, IgG3, IgA, C3c and C3d on patient's erythrocytes. These findings suggested a diagnosis of $\mathrm{PCH}$. Similar high-titer cold agglutinins (titer 1024 at $4^{\circ} \mathrm{C}$ ) were reported earlier ${ }^{5,6}$. It results from the formation of polyclonal $\mathrm{IgG}$ antibody directed against $\mathrm{P}$ antigen and may induce antibody-dependent complement-mediated hemolysis. $\mathrm{PCH}$ is known to cause acute intravascular hemolysis. It may contribute as $10 \%$ of autoimmune cold hemolytic anemias. It may occur either as a primary idiopathic disease or secondary to viral infection. Another case had above immune components along with IgM. Presence of IgM suggested a diagnosis of CAD which is known to cause mild anemia. Our third patient (no.3) was different 
from previous 2 patients. Erythrocytes from this patient had low-titer anti human Ig and C3d, suggesting deagglutination or dissociation of immunoglobulins from patient's erythrocytes. Anti C3d activity is important for the direct antiglobulin test in the investigation of acquired immune haemolytic anemia. Low-titer cold agglutinins may be present physiologically in normal healthy individuals. However, high-titer narrow-thermal-range cold agglutinins may contribute to anemia. Results of characterization of immune complexes suggested pathological role of cold agglutinins in haemolytic anemia. Retuximab (anti CD20) therapy may decrease the levels of cryoglobulins and may also improve complement levels ${ }^{1,2,6}$. Though cryoglobulins are different from cold agglutinins, Rituximab may be useful in the treatment of cold agglutinin-induced haemolytic anemia. In addition, EBV transformed B-cell lines/clones may produce anti-Pr2 cold agglutinins similar to the pathogenic cold auto antibodies in patients' plasma ${ }^{7}$. Some patients with CAD may have a relative deficit of complement in their sera. An increase in complement production occurs during an acute phase reaction which may enhance haemolysis ${ }^{8}$.

\section{Conclusion}

Cold agglutinin test for anti I antibody was positive in 3 patients. In addition, $\operatorname{IgM}, \operatorname{IgG}, \operatorname{IgA}$ and complement components ( $\mathrm{C} 3 \mathrm{c}$ and $\mathrm{C} 3 \mathrm{~d}$ ) were detected on a patient's erythrocytes. Another patient had C3d on erythrocytes. These 2 cases were diagnosed to have cold agglutinin disease. Another patient had $\operatorname{IgG}$ on erythrocytes, suggesting Paroxysmal cold hemoglobinuria. Results of this study suggested possible role of cold agglutinins in pathogenesis of autoimmune hemolytic anemia. Treatment consisted of keeping the patient warm and use of Rituximab.

\section{References}

1. Gertz MA. Cold agglutinin disease and cryoglobulinemia. Clinical lymphoma 2005; 5 : 290-293.
2. Berentsen S, Ulvestad E, Langholm R, Beiske K, Hjorth-Hansen H, Ghanima W, Sorbo JH, Tjonnfjord GE. Primary chronic cold agglutinin disease: A population based clinical study of 86 patients. Haematologica 2006;91:460-466.

3. Worlledge SM. The interpretation of a positive direct antiglobulin test. Brit $\mathrm{J}$ haematol 1978, 39; 157-162.

4. Bain Barbara J, Nay W. Acquired haemolyticanaemia. In Dacie and Lewis Practical haematology, chapter $13,11^{\text {th }}$ edition 2012, p273-300.

5. Petz ID, Garrathy G. Acquired immune hemolytic anaemia, $2^{\text {nd }}$ ed. New York : Churchill Livingstone, 2004.

6. Morselli M, Luppi M, Potenza $\mathrm{T}$ et al. Mixed warm and cold autoimmune hemolytic anemia: complete recovery after rituximab treatment. Blood 2002; 99 : 3478-3479.

7. Silberstein Leslie E, Goldman J, Kant JA, Spitalnik SL. Comparative biochemical and genetic characterization of clonally related B-cell lines secreting anti-Pr2 Cold agglutinins, Arch Biochem and Biophysica 1988; 264, 244-252.

8. Ulvestad E, Berentsen S, Bo Kristine, Shammas FV. Clinical immunology of chronic cold agglutinin disease. 1999; 63 : 259-266. 